\title{
Technological properties and probiotic potential of Lactobacillus fermentum strains isolated from West African fermented millet dough
}

James Owusu-Kwarteng ${ }^{1}$, Kwaku Tano-Debrah², Fortune Akabanda ${ }^{1 *}$ and Lene Jespersen ${ }^{3}$

\begin{abstract}
Background: Throughout Africa, food fermentations are still driven by indigenous microorganisms which influence the nutritional, organoleptic and safety of the final products. However, for improved safety, consistent quality and beneficial health effects, a trend has emerged which involves the isolation of indigenous strains from traditional fermented products to be used as functional starter cultures. These functional starter cultures possess inherent functional characteristics and can contribute to food quality and safety by offering one or more organoleptic, nutritional, technological or health advantage (probiotics). With the aim of selecting potential probiotic starter cultures, Lactobacillus fermentum strains isolated from fermented millet dough were investigated for technological properties and probiotic traits in-vitro.
\end{abstract}

Results: A total of $176 \mathrm{~L}$. fermentum strains were assessed for technological properties including rate of acidification, exopolysaccharide production and amylase activity. Following this, 48 strains showing desirable technological properties were first screened for acid resistance. Sixteen acid resistant strains were assessed for additional probiotic properties including resistance to bile salts, bile salt hydrolysis, antimicrobial property, haemolysis and antibiotics resistance. L. fermentum strains clustered into 3 groups represented by $36 \%, 47 \%$ and $17 \%$ as fast, medium and slow acidifiers respectively. About $8 \%, 78 \%$ and $14 \%$ of the strains showed strong, weak and no exopolysaccharides production respectively. Amylase activity was generally weak or not detected. After exposure of $48 \mathrm{~L}$. fermentum strains to $\mathrm{pH} 2.5$ for $4 \mathrm{~h}, 16$ strains were considered to be acid resistant. All 16 strains were resistant to bile salt. Four strains demonstrated bile salt hydrolysis. Antimicrobial activity was observed towards Listeria monocytogenes and Staphylococcus aureus but not E. coli and Salmonella enteritidis. Lactobacillus fermentum strains were generally susceptible to antibiotics except 6 strains which showed resistance towards streptomycin, gentamicin and kanamycin.

Conclusion: In vitro determination of technological and probiotic properties have shown strain specific difference among L. fermentum strains isolated from fermented millet dough. Sixteen (16) L. fermentum strains have been shown to possess desirable technological and probiotic characteristics in vitro. These strains are therefore good candidates for further studies to elucidate their full potential and possible application as novel probiotic starter cultures.

Keywords: Starter culture, Lactobacillus fermentum, Cereal, Traditional fermentation, Probiotics traits

\footnotetext{
* Correspondence: fakabanda@gmail.com

${ }^{1}$ Department of Applied Biology, Faculty of Applied Sciences, University for Development Studies, P. O. Box 24, Navrongo Campus, Navrongo, Ghana Full list of author information is available at the end of the article
} 


\section{Background}

The consumption of fermented foods contribute immensely to human diet in many countries around the world. Throughout Africa, food fermentations are still driven by indigenous microorganisms in the raw ingredients [1-3] which influence the nutritional availability, organoleptic quality and safety of the final products [4, 5]. However, for improved safety and the production of fermented foods with consistent quality and beneficial health effects, a trend has emerged which involves the isolation of wild-type strains from traditional fermented products to be used as functional starter cultures in food fermentation [6, 7]. These functional starter cultures are starters that possess inherent functional characteristics and can contribute to food quality and safety by offering one or more organoleptic, nutritional, technological or health advantage (probiotics) [8]. Thus, the implementation of carefully selected strains as starter cultures or co-cultures in fermentation processes can help to achieve in situ expression of the desired property, maintaining a perfectly natural product and still function as probiotics (impart health benefit unto the consumer) where applicable.

Lactobacillus fermentum has been identified as the predominant lactic acid bacteria (LAB) specie in several African cereal based fermented foods [1, 3, 9-12]. The predominance of L. fermentum during koko production, a millet-based fermented porridge in northern Ghana, was reported by Lei and Jakobsen [11] and the biodiversity of $L$. fermentum in their study was revealed by pulsed field gel electrophoresis (PFGE) and by multivariate data analysis. Similar results were demonstrated by randomly amplified polymorphic DNA (RAPD)-PCR fingerprinting patterns for fermented maize [9]. The technological roles of L. fermentum including acidification and aroma formation has also been described for Ghanaian fermented maize dough [13, 14]. Despite the significant importance of $L$. fermentum in food fermentation, strains of this species isolated from spontaneously fermented food products in Africa are still rarely dealt with in scientific publications and detailed examinations of their technological properties, their ability to survive the passage of the gastrointestinal tract as well as their susceptibility to common antibiotics are still missing.

In a framework to describe specific characteristics of L. fermentum strains isolated from African fermented cereals and to select and develop functional starter cultures with probiotic effect for the production of traditional fermented foods, predominant microorganisms associated with the traditional processing of fura, a millet based fermented food in Ghana were first isolated and identified $[1,2]$. In this paper, L. fermentum strains originating from traditionally fermented millet dough were evaluated for their technological properties. Their ability to survive the passage of the gastro-intestinal tract, haemolytic activities, antimicrobial properties and susceptibility to several antibiotics were investigated. This is geared towards the selection and further development of probiotic starter cultures.

\section{Methods}

\section{Bacterial strains}

A total of 176 L. fermentum strains, isolated from spontaneously fermented millet dough were screened for some technological and probiotic properties, following a series of in vitro tests. The L. fermentum strains were previously isolated and identified by $(\mathrm{GTG})_{5}$ - based rep-PCR fingerprinting and sequencing of their 16S rRNA [GenBank: JF268321 - JF268326], as described by [1].

Indicator strains for antimicrobial activity included Escherichia coli O157 882364, Salmonella enteritidis ATCC 13076, Listeria monocytogenes NCTC 10527 and Staphylococcus aureus ATCC 1448 which were cultured and maintained in Luria-Bertani (LB), Nutrient Broth (NB), Brain-Heart Infusion (BHI) and Tryptic Soy (TS) media respectively.

\section{Determination of technological properties Acidification of millet broth}

Fermentations trials were conducted by inoculating $L$. fermentum isolates into sterile millet broth and measuring the change in $\mathrm{pH}$ over time. For the preparation of millet broth, whole millet grains were cleaned by washing three times with distilled water. The washed grains were dried in an oven at $60{ }^{\circ} \mathrm{C}$ for $90 \mathrm{~min}$ and dry milled using a disc plate attrition mill (Hunt no. 2A \& Co., Kent, UK). Millet broth was prepared as an aqueous suspension $10 \%(\mathrm{w} / \mathrm{v})$ in distilled water, dispensed into conical flasks (200 $\mathrm{ml}$ per flask) and autoclaved at $115{ }^{\circ} \mathrm{C}$ for $10 \mathrm{~min}$. A loopful of an overnight culture was collected from MRS agar, transferred into $10 \mathrm{ml}$ MRS broth and incubated at $30{ }^{\circ} \mathrm{C}$ for $24 \mathrm{~h}$. About $100 \mu \mathrm{l}$ of the $24 \mathrm{~h}$ old culture were transferred into $10 \mathrm{ml}$ MRS broth and incubated at $30{ }^{\circ} \mathrm{C}$ for $16 \mathrm{~h}$. Subsequently, cells were harvested by centrifugation at $5000 \mathrm{~g}$ for $10 \mathrm{~min}\left(4{ }^{\circ} \mathrm{C}\right)$, washed three times with $20 \mathrm{ml}$ sterile diluent $[0.1 \%(\mathrm{w} / \mathrm{v})$ peptone, $0.85 \%(\mathrm{w} / \mathrm{v}) \mathrm{NaCl}, \mathrm{pH} 7.2 \pm 0.2$ ], and finally re-suspended in $10 \mathrm{ml}$ of sterile diluent. This suspension served as the isolate inoculum and was sampled for viable cell count on MRS agar. Flasks containing $200 \mathrm{ml}$ of autoclaved millet broth were inoculated in duplicates to obtain initial cell counts of $\mathrm{ca} 10^{6} \mathrm{cfu} /$ $\mathrm{ml}$, and incubated at $35{ }^{\circ} \mathrm{C}$. About $200 \mathrm{ml}$ of sterile millet broth served as a negative control. Samples were aseptically collected at $3 \mathrm{~h}$ intervals over $24 \mathrm{~h}$ period for measurement of $\mathrm{pH}$. 


\section{Exopolysaccharide production}

The screening of $L$. fermentum isolates for their ability to produce exopolysaccharide (EPS) was carried out as described by [15]. Bacterial cells from fresh overnight $(18 \mathrm{~h})$ cultures on MRS agar were streaked on LTV agar [0.5 g/l tryptone, $10 \mathrm{~g} / \mathrm{l}$ meat extract, $6.5 \mathrm{~g} / \mathrm{l} \mathrm{NaCl}, 8 \mathrm{~g} / \mathrm{l}$ potassium nitrate, $8 \mathrm{~g} / \mathrm{l}$ sucrose, $0.1 \%(\mathrm{v} / \mathrm{v})$ Tween 80 , $17 \mathrm{~g} / \mathrm{l}$ agar, $\mathrm{pH} 7.1 \pm 0.2$ ] and incubated at $35{ }^{\circ} \mathrm{C}$ for $48 \mathrm{~h}$. The stickiness of colonies were determined by the inoculating loop method [16]. Isolates were tentatively considered positive for exopolysaccharide if the length of slime was above $1.5 \mathrm{~mm}$. Positive isolates were confirmed using MRS - sucrose broth without glucose and peptone as follows: $[1 \%(\mathrm{w} / \mathrm{v})$ meat extract, $5 \mathrm{~g} / \mathrm{l}$ yeast extract, $50 \mathrm{~g} / \mathrm{l}$ sucrose, $2 \mathrm{~g} / 1 \mathrm{~K}_{2} \mathrm{HPO}_{4} 3 \mathrm{H}_{2} \mathrm{O}, 5 \mathrm{~g} / \mathrm{l}$ sodium acetate trihydrate, $2 \mathrm{~g} / \mathrm{l}$ triammonium citrate anhydrous, $0.2 \mathrm{~g} / \mathrm{l} \mathrm{MgSO}_{4} .7 \mathrm{H}_{2} \mathrm{O}, 0.05 \mathrm{~g} / \mathrm{l}$ manganese (II) sulphate monohydrate, $0.1 \%(\mathrm{v} / \mathrm{v})$ Tween $80, \mathrm{pH} 5.0 \pm 0.2$ ]. The isolates were then incubated at $30{ }^{\circ} \mathrm{C}$ for $24 \mathrm{~h}$. A volume of $1.5 \mathrm{ml}$ of the $24 \mathrm{~h}$ culture was centrifuged at $5000 \mathrm{~g}$ for $10 \mathrm{~min}\left(4^{\circ} \mathrm{C}\right)$. About $1 \mathrm{ml}$ of the supernatant was put in a glass tube and an equal volume of ethanol (99 \%) was added. In the presence of EPSs, an opaque link is formed at the interface.

\section{Amylase activities}

The ability of L. fermentum to produce amylase was determined according to the method described by [17]. Active cultures of LAB isolates were point-inoculated on modified MRS agar without glucose but with potato soluble starch as the sole carbon source. The media composition was as follows: [ $10 \mathrm{~g} / \mathrm{l}$ tryptone, $10 \mathrm{~g} / \mathrm{l}$ meat extract, $5 \mathrm{~g} / \mathrm{l}(\mathrm{w} / \mathrm{v})$ yeast extract, $20 \mathrm{~g} / \mathrm{l}$ potato-soluble starch, $2 \mathrm{~g} / \mathrm{l} \mathrm{K}_{2} \mathrm{HPO}_{4} \cdot 3 \mathrm{H}_{2} \mathrm{O}, 5 \mathrm{~g} / \mathrm{l}$ sodium acetate, $2 \mathrm{~g} / \mathrm{l}$

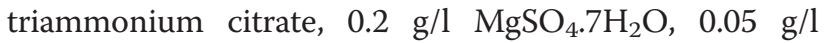
manganese (II) sulphate monohydrate, $0.1 \%$ (v/v) Tween 80, pH 5.0 \pm 0.2 ]. Inoculated plates were incubated anaerobically (AnaeroGen, oxoid) at $35{ }^{\circ} \mathrm{C}$ for $48 \mathrm{~h}$. The culture plates were covered by spraying with Lugol's iodine [0.33 \% (w/v) iodine, $0.66 \%(\mathrm{w} / \mathrm{v})$ potassium iodide] to detect starch hydrolysis. Un-degraded starch stains blue-black while the presence of a clear halo zone around a tested colony was taken as indication of starch degradation and therefore the production of $\alpha$ amylase. Diameters of the halos around colonies were measured.

\section{Determination of probiotic properties Resistance to low $\mathrm{pH}$}

Resistance to low $\mathrm{pH}$ was determined according to [18] and [19]. Bacterial cells from fresh overnight $(18 \mathrm{~h})$ cultures were harvested $\left(10,000 \mathrm{x} \mathrm{g}, 5 \mathrm{~min}, 4{ }^{\circ} \mathrm{C}\right)$, washed twice with PBS buffer ( $\mathrm{pH} 7.2)$, re-suspended (2\%) in PBS solution and adjusted to $\mathrm{pH} 2.5$. Resistance was assessed in triplicates in terms of viable colony counts and enumerated on MRS agar (Merck) after incubation at $37{ }^{\circ} \mathrm{C}$ for $4 \mathrm{~h}$, reflecting the possible time spent by food in the stomach.

\section{Resistance to bile salts and bile salt hydrolysis}

Bacterial cells from overnight $(18 \mathrm{~h})$ cultures were harvested $\left(10,000 \times \mathrm{g}, 5 \mathrm{~min}, 4^{\circ} \mathrm{C}\right)$, washed twice with PBS buffer ( $\mathrm{pH}$ 7.2), before inoculating in PBS solution ( $\mathrm{pH} 8.0$ ), containing $0.3 \%, 0.5 \%, 1 \%$ and $2 \%(\mathrm{w} / \mathrm{v})$ bile salt (Oxgall, Difco). Resistance was assessed in triplicates in terms of viable colony counts and enumerated after incubation at $37^{\circ} \mathrm{C}$ for $4 \mathrm{~h}$.

For the determination of bile salt hydrolysis (BSH), fresh bacterial cultures were streaked in triplicates on MRS agar containing $0.5 \%(\mathrm{w} / \mathrm{v})$ taurodeoxycholic acid (Sigma). The hydrolysis effect was indicated by different colony morphology from the control MRS plates, after $48 \mathrm{~h}$ of anaerobic incubation at $37^{\circ} \mathrm{C}$.

\section{Estimation of survival rates}

Survival rates for L. fermentum strains were estimated after their growth in low $\mathrm{pH}(\mathrm{pH} 2.5)$ and different bile salt concentrations $(0.3 \%, 0.5 \%, 1 \%$ and $2 \%)$.

\section{Haemolytic activity}

Fresh bacterial cultures were streaked in triplicates on Columbia agar plates, containing $5 \%$ (w/v) human blood (Michopoulos S.A., Athens, Greece), and incubated at $37{ }^{\circ} \mathrm{C}$ for $48 \mathrm{~h}$ under anaerobic condition. Blood agar plates were examined for signs of $\beta$-haemolysis (clear zones around colonies), $\alpha$-haemolysis (green-hued zones around colonies) or $\gamma$-haemolysis (no zones around colonies).

\section{Antimicrobial activity}

Fresh overnight $L$. fermentum culture supernatants were collected by centrifugation $\left(10,000 \times \mathrm{g}, 15 \mathrm{~min}, 4{ }^{\circ} \mathrm{C}\right)$, adjusted to $\mathrm{pH} 6.5$ and filter-sterilised $(0.20 \mu \mathrm{m})$. The cell-free culture supernatants (CFCS) of the potential probiotic strains were screened for inhibitory activity against indicator pathogens (described in section 2.1) using the agar well diffusion method. Briefly, an initial inoculum of approximately $10^{6} \mathrm{cfu} / \mathrm{ml}$ of the target strain was incorporated into soft agar $(1 \%, w / v)$ plates of the appropriate medium for the indicator strain. CFCS $(50 \mathrm{~mL})$ were transferred into wells $(5 \mathrm{~mm}$ diameter) drilled into the agar. The plates were incubated at $37{ }^{\circ} \mathrm{C}$ for $24 \mathrm{~h}$, and the antimicrobial activity was recorded as inhibition zones (diameter) around the well. Kanamycin $(30 \mathrm{mg} / \mathrm{ml})$ was used as positive control, while MRS broth, adjusted to $\mathrm{pH} 6.5$ and filtered served as the negative control. 


\section{Antibiotic resistance}

For antibiotic resistance test, L. fermentum strains were inoculated $(1 \% \mathrm{v} / \mathrm{v})$ in MRS broth supplemented with 9 different antibiotics (Ampicillin, Chloramphenicol, Tetracycline, Erythromycin, Streptomycin, Kanamycin, Gentamycin, Quinupristin/Dalfopristin, Clindamycin) at various final concentrations $(1,2,4,8,16,32,64,128,256,512$, and $1024 \mu \mathrm{g} / \mathrm{ml}$ ) and examined in triplicate for growth in a microplate reader (OD at $610 \mathrm{~nm}$ ) following a $24 \mathrm{~h} \mathrm{incu-}$ bation period at $35^{\circ} \mathrm{C}$.

\section{Results and discussion}

\section{Acidification properties in millet broth}

Lactobacillus fermentum strains were clustered into three groups according to their acidification properties (Fig. 1). Lactobacillus fermentum isolates representing $36 \%$ (fast acidifiers) and $47 \%$ (moderate acidifiers) were able to obtain a change in $\mathrm{pH}(\Delta \mathrm{pH})$ of 2 units after $9 \mathrm{~h}$ and $12 \mathrm{~h}$ of fermentation respectively. However, a third group of L. fermentum strains (slow acidifiers) representing $17 \%$ of the total L. fermentum strains never attained $\mathrm{pH}$ change up to $2 \mathrm{pH}$ units. The demonstration of faster acidification property by L. fermentum strains is a required technological property for the development of starter cultures for controlled fermentation processes as faster acidification is necessary for reducing fermentation time and reducing contamination by spoilage and/ or pathogenic microorganisms.

\section{Exopolysaccharide production and amylase activity}

Amylase activity and exopolysaccharides production by L. fermentum isolated from fermented millet are shown in Table 1. Amylase activity of the L. fermentum strains were generally weak or not detected. About $16.5 \%$ of the total strains only showed weak amylolytic activity. Out of a total of 176 strains of L. fermentum, about 85.6 $\%$ showed slime formation while $14.4 \%$ showed no slime formation or exopolysaccharides production.

Generally, high prevalence of amylase producing LAB has not been reported. However, few strains of $L$. fermentum isolated from fermented maize products have been reported as amylase producers [17, 20]. Amylolytic lactic acid bacteria from traditional fermented foods could be of economic interest in the production of lactic acid from direct fermentation of starchy products $[21,22]$. Additionally, they may present the potential for decreasing the viscosity of bulky, starchy, weaning porridges which may enable an improvement in their nutrient density while maintaining an acceptable thickness for feeding young children in developing countries [23].

The ability of $L$. fermentum strains to produce EPS is not surprising since previous studies have shown that many food grade microorganisms produce EPS [12, 24]. Technologically, the physicochemical properties of EPS, such as viscosity, have motivated their utilization in food applications as, for example, biothickeners [24, 25]. Therefore, texture which is an important attribute associated with the consumption of traditional fermented cereal products will be affected by EPS produced by the selected L. fermentum starter cultures. Interestingly, The L. fermentum strains which produced EPS were found to be resistant to low $\mathrm{pH}$ condition (Table 5). The production of EPS has been reported to protect the producing

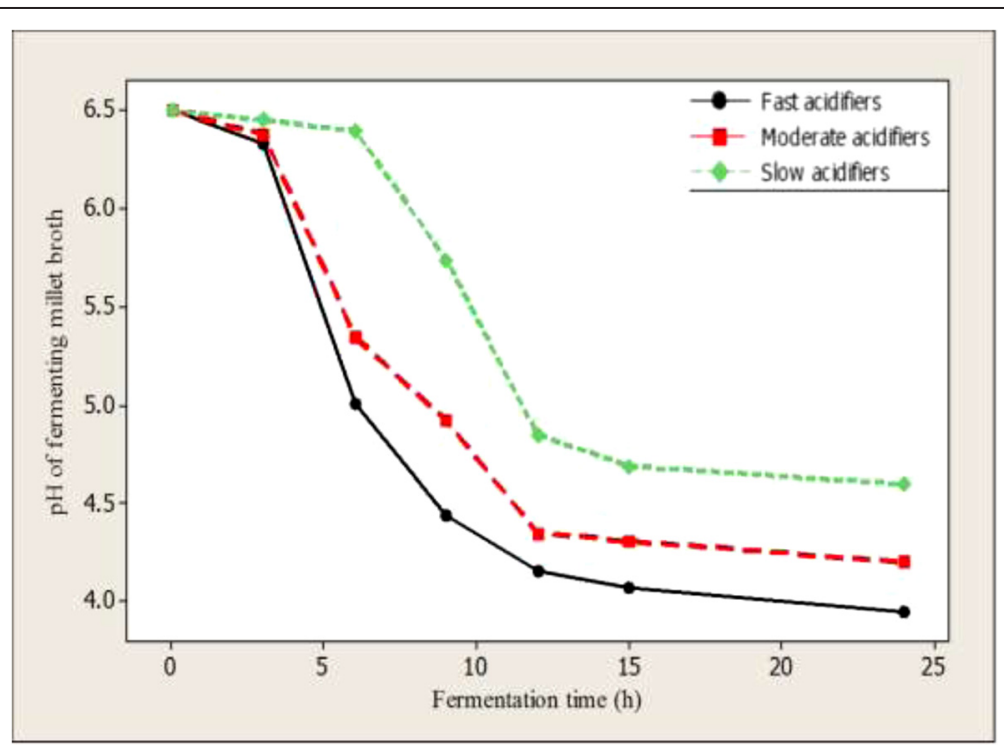

Fig. 1 Rate of acidification by L. fermentum strains isolated from traditionally fermented millet dough. Values represent means \pm standard errors of two independent experiments carried out in triplicate. The Tukey-Kramer test was used for comparison of means. Means with different capital alphabets are significantly different $(P<0.05)$ for each time point 
Table 1 Amylase activity and exopolysaccharides production by L. fermentum

\begin{tabular}{llllll}
\hline & & \multicolumn{4}{l}{ Clear zone around colonies/slime length ${ }^{\text {a }}$} \\
\cline { 2 - 6 } Microbial specie & Activity & - & + & ++ & + \\
\hline L. fermentum $(n=176)$ & Amylase & 83.5 & 16.5 & 0 & 0 \\
& Exopolysaccharide & 14.4 & 38.4 & 39.2 & 8.4 \\
\hline
\end{tabular}

${ }^{a}$ Values are percentages (\%) of the total number ( $n$ ) of $L$. fermentum strains

- No clear zone around colony or slime formation observed, + diameter of clear zone or slime length of $<1.5 \mathrm{~mm},++$ diameter of clear zone or slime length of 1.5 $-3 \mathrm{~mm},+++$ diameter of clear zone or slime length $>3 \mathrm{~mm}$

microorganisms against dehydration and other harsh conditions such as acid and bile [26, 27], and may also contribute to the aggregation properties required for colonisation by probiotic lactic acid bacteria [28, 29].

\section{Resistance to low pH}

Following a determination of technological properties, $48 \mathrm{~L}$. fermentum strains were further assessed for resistance to low $\mathrm{pH}$ (2.5) in PBS over $4 \mathrm{~h}$ duration (Table 2). Using a survival rate of $\geq 80 \%$ after incubation at $\mathrm{pH} 2.5$ for $4 \mathrm{~h}, 16 \mathrm{~L}$. fermentum strains were considered to be resistant to low $\mathrm{pH} 2.5$ and were selected for further screening. This results confirm the strain-specific differences which exist among lactobacilli in relation to their probiotic properties. Similar results were obtained from previous reports, where Lactobacillus strains of food, human or animal origin, were able to retain their viability when exposed to low $\mathrm{pH}$ values between 2.5 and 4.0 [18, $30-34]$. The $\mathrm{pH}$ value in human stomach may ranges from 1.5, during fasting, to 4.5, after a meal, and food ingestion can take up to $3 \mathrm{~h}$ [35]. The $\mathrm{pH}$ value (2.5) and $4 \mathrm{~h}$ duration used in this study for the selection of potential probiotic L. fermentum strains is very selective and even though it is not the most common condition in the human stomach, it assures the selection of the very acid-tolerant strains [36].

In order for probiotic bacteria to fulfil their physiological role in the gut, the bacteria must overcome a number of stresses before they reach the target site [37]. The acidic environments encountered both in food and in the gastrointestinal tract provide a significant survival challenge for probiotic organisms. For example, the preferred delivery vehicles for probiotic cultures are acid fermented food products which present an acid challenge. In a situation where the probiotic bacteria is used as a starter culture for the fermentation, the potential probiotic organism require mechanisms to survive the adverse effects of the by-products (organic acids) of their own metabolism. In addition to their ability to survive the harsh environments encountered during processing, the bacteria will need to survive the highly acidic gastric juice if they are to reach the small intestine in a viable state [38]. Passage of probiotics through the gastrointestinal tract (GIT) is a stressful journey, with stress stages which may affect cell viability. The principal stress is that of shifting $\mathrm{pH}$ encountered in the stomach, resulting from gastric acid as well as bile $[39,40]$. Hence, acid tolerance is accepted as one of the desirable properties used to select potentially probiotic strains.

\section{Resistant to bile and bile salts hydrolysis}

The ability of L. fermentum strains to tolerate the effect of different concentrations of bile salt after incubation for $4 \mathrm{~h}$ is shown in Fig. 2. All 16 tested L. fermentum showed resistance (survival rate $\geq 80 \%$ ) to $0.3 \%$ bile salt. However, resistance decreased significantly $(\mathrm{P}<0.05)$ with increasing bile salt concentration.

The detergent property of bile confers potent toxicity, primarily through the dissolution of bacterial membranes [41]. Therefore, for a probiotic strain to be able to perform effectively in the gastrointestinal tract, it must overcome the antimicrobial challenge posed by bile. Thus in vitro resistance to bile has become necessary in screening potential probiotic strains as one of the physiologically relevant stresses in the gastrointestinal tract $[33,42]$.

While all L. fermentum strains in this study were able to grow in the presence of bile salt, only four (4) strains demonstrated the ability to hydrolyse taurodeoxycholic acid (TDCA), as indication of in vitro bile salt hydrolyse (BSH) activity. Some authors have suggested that $\mathrm{BSH}$ activity and resistance to toxicity of conjugated bile salts are unrelated properties in lactobacilli $[43,44]$. The ability of probiotic strains to hydrolyse bile salts has often been included among the criteria for probiotic strain selection [45], although there are divided views on whether microbial bile salt hydrolase (BSH) activity is a desirable trait for probiotic strains. On one hand, blood cholesterol lowering effect has been correlated to the bile salt hydrolase activity of some lactobacilli $[45,46]$. On the other hand, unconjugated bile acids are less efficient molecules in the emulsification of dietary lipids and so BHS may compromise normal lipid digestions, and subsequently, the absorption of fatty acids and monoglycerides could be impaired [47]. In general however, there is sufficient data to suggest that microbial BSH-activity function in the detoxification of bile salts increases the intestinal survival and persistence of producing strains, which in turn increases the overall beneficial effects associated with a probiotic strain $[41,45]$. 
Table 2 Acid resistance of $48 \mathrm{~L}$. fermentum strains grown in PBS at $\mathrm{pH} 2.5$ for $4 \mathrm{~h}$

\begin{tabular}{|c|c|c|c|}
\hline \multirow[t]{2}{*}{ Strains } & \multicolumn{2}{|c|}{ Viable count $(\log \mathrm{cfu} / \mathrm{ml})^{\mathrm{a}}$} & \multirow[t]{2}{*}{ Survival rate $(\%)^{\mathrm{b}}$} \\
\hline & $\mathrm{Oh}$ & $4 \mathrm{~h}$ & \\
\hline L. fermentum 6-6 & $8.87 \pm 0.02$ & $7.36 \pm 0.11$ & 83.0 \\
\hline L. fermentum f-7 & $9.11 \pm 0.06$ & $8.05 \pm 0.04$ & 88.4 \\
\hline L. fermentum f-17 & $9.05 \pm 0.10$ & $6.48 \pm 0.12$ & 71.6 \\
\hline L. fermentum 6-1 & $8.70 \pm 0.05$ & $4.33 \pm 0.03$ & 49.8 \\
\hline L. fermentum 6-2 & $9.21 \pm 0.05$ & $6.00 \pm 0.08$ & 65.1 \\
\hline L. fermentum 10-4 & $9.03 \pm 0.13$ & $3.58 \pm 0.05$ & 39.6 \\
\hline L. fermentum 10-9 & $9.45 \pm 0.04$ & $8.20 \pm 0.00$ & 86.8 \\
\hline L. fermentum f-26 & $9.20 \pm 0.06$ & $7.04 \pm 0.02$ & 76.5 \\
\hline L. fermentum f-29 & $9.18 \pm 0.03$ & $8.10 \pm 0.06$ & 88.2 \\
\hline L. fermentum 10-1 & $8.84 \pm 0.11$ & $3.65 \pm 0.09$ & 41.3 \\
\hline L. fermentum 12-5 & $8.92 \pm 0.08$ & $5.54 \pm 0.05$ & 62.1 \\
\hline L. fermentum 10-3 & $9.00 \pm 0.01$ & $6.35 \pm 0.05$ & 70.6 \\
\hline L. fermentum 4-12 & $8.96 \pm 0.15$ & $4.08 \pm 0.10$ & 45.5 \\
\hline L. fermentum 12-18A & $9.10 \pm 0.07$ & $8.26 \pm 0.06$ & 90.8 \\
\hline L. fermentum 12-19A & $9.37 \pm 0.05$ & $7.99 \pm 0.12$ & 85.3 \\
\hline L. fermentum 12-20A & $9.05 \pm 0.08$ & $8.35 \pm 0.03$ & 92.3 \\
\hline L. fermentum $12-6 \mathrm{~A}$ & $9.38 \pm 0.15$ & $4.82 \pm 0.10$ & 51.4 \\
\hline L. fermentum 8-16A & $9.33 \pm 0.06$ & $3.50 \pm 0.08$ & 37.5 \\
\hline L. fermentum 4-20 & $8.66 \pm 0.02$ & $7.58 \pm 0.10$ & 87.5 \\
\hline L. fermentum 4-12A & $9.35 \pm 0.05$ & $4.65 \pm 0.06$ & 49.7 \\
\hline L. fermentum f-11A & $9.22 \pm 0.08$ & $4.05 \pm 0.12$ & 45.0 \\
\hline L. fermentum f-22 & $9.40 \pm 0.04$ & $5.50 \pm 0.05$ & 58.5 \\
\hline L. fermentum $\mathrm{f}-2 \mathrm{~A}$ & $8.78 \pm 0.05$ & $4.80 \pm 0.10$ & 54.1 \\
\hline L. fermentum 2-15 & $9.08 \pm 0.10$ & $8.20 \pm 0.14$ & 90.3 \\
\hline L. fermentum 2-3A & $9.08 \pm 0.07$ & $6.18 \pm 0.04$ & 68.0 \\
\hline L. fermentum 6-13A & $9.20 \pm 0.15$ & $3.95 \pm 0.10$ & 42.9 \\
\hline L. fermentum 0-17 & $9.35 \pm 0.06$ & $8.00 \pm 0.07$ & 85.6 \\
\hline L. fermentum 2-23A & $9.28 \pm 0.10$ & $3.20 \pm 0.14$ & 34.5 \\
\hline L. fermentum 8-10 & $9.64 \pm 0.10$ & $7.95 \pm 0.08$ & 82.5 \\
\hline L. fermentum 0-25A & $9.50 \pm 0.04$ & $8.06 \pm 0.15$ & 84.8 \\
\hline L. fermentum 10-31 & $9.00 \pm 0.06$ & $6.50 \pm 0.04$ & 72.2 \\
\hline L. fermentum 2-14A & $9.47 \pm 0.12$ & $4.45 \pm 0.10$ & 46.9 \\
\hline L. fermentum f-5A & $8.85 \pm 0.07$ & $8.11 \pm 0.05$ & 91.6 \\
\hline L. fermentum f-22A & $8.91 \pm 0.05$ & $3.80 \pm 0.12$ & 42.6 \\
\hline L. fermentum 12-15 & $8.80 \pm 0.15$ & $5.65 \pm 0.06$ & 64.2 \\
\hline L. fermentum 10-19A & $9.06 \pm 0.07$ & $3.90 \pm 0.10$ & 43.0 \\
\hline L. fermentum 10-24 & $7.98 \pm 0.10$ & $4.00 \pm 0.08$ & 50.1 \\
\hline L. fermentum 10-16A & $9.18 \pm 0.08$ & $5.45 \pm 0.15$ & 59.4 \\
\hline L. fermentum 8-13 & $9.50 \pm 0.14$ & $4.85 \pm 0.05$ & 51.1 \\
\hline L. fermentum 8-5A & $9.06 \pm 0.06$ & $7.30 \pm 0.10$ & 80.6 \\
\hline L. fermentum 8-20 & $9.35 \pm 0.08$ & $6.03 \pm 0.07$ & 64.5 \\
\hline L. fermentum 8-28 & $9.28 \pm 0.12$ & $8.45 \pm 0.09$ & 91.1 \\
\hline
\end{tabular}

Table 2 Acid resistance of $48 \mathrm{~L}$. fermentum strains grown in PBS at $\mathrm{pH} 2.5$ for $4 \mathrm{~h}$ (Continued)

\begin{tabular}{llll}
\hline L. fermentum 6-18A & $9.09 \pm 0.10$ & $6.60 \pm 0.10$ & 72.6 \\
L. fermentum 6-23 & $9.11 \pm 0.06$ & $5.84 \pm 0.05$ & 64.1 \\
L. fermentum 4-30 & $\mathbf{9 . 3 6} \pm \mathbf{0 . 0 8}$ & $\mathbf{8 . 0 0 \pm 0 . 1 6}$ & $\mathbf{8 5 . 5}$ \\
L. fermentum 4-16A & $9.20 \pm 0.14$ & $5.36 \pm 0.09$ & 58.3 \\
L. fermentum 4-10A & $8.97 \pm 0.05$ & $2.66 \pm 0.15$ & 29.7 \\
L. fermentum 12-7 & $9.06 \pm 0.10$ & $3.50 \pm 0.07$ & 38.6
\end{tabular}

Values are means \pm standard deviation of two independent experiments

bacid resistant strains with mean survival rates $\geq 80 \%$ after $4 \mathrm{~h}$ in are in bold

\section{Antimicrobial activity}

None of the cell free neutralized supernatant $(\mathrm{pH}$ 6.5) showed antimicrobial activities against the pathogenic strains Escherichia coli O157 882364 and Salmonella enteritidis ATCC 13076. However, four L. fermentum strains (i.e. 10-9, 4-20, 0-17 and 4-30) showed inhibitions towards Listeria monocytogenes NCTC 10527 and Staphylococcus aureus ATCC 1448 (Table 3.). Previous reports on probiotic L. fermentum strains showed negligible antimicrobial activity in neutral pH 7.0 [48]. Moreover, it has been reported that neutralization of the soluble fraction to $\mathrm{pH} 6.5$ significantly reduced the antimicrobial activity against pathogens [49].

The prevention of gastrointestinal tract colonization by a variety of pathogens is a primary mechanism of beneficial effects mediated by probiotics [50]. The mechanisms underlying the antimicrobial activity of lactobacilli are believed to involve the production of different kinds of inhibitory substances and competitive exclusion [51]. The capacity to produce different antimicrobial compounds may be one of the critical characteristics for effective competitive exclusion of pathogen survival in the intestine and expression of a probiotic effect for the host [52]. The acidic conditions in the stomach may also enhance the activity of these antimicrobial compounds [53]. Furthermore, these probiotic characteristics may partly be based on the production of relevant concentrations of lactic acid in the microenvironment, which, in combination with a detergent such as bile salts, inhibits the growth of Gram-negative pathogenic bacteria [41]. However, antimicrobial mechanisms other than those driven by bacterial metabolites may play a significant role the antimicrobial property of probiotic in vivo.

\section{Haemolytic activity}

None of the tested L. fermentum strains showed $\beta$ haemolytic activity. However, L. fermentum $0-25 \mathrm{~A}$ and L. fermentum 12-18A showed $\alpha$-haemolytic activity. Thus, almost all L. fermentum strains isolated from fermented millet dough expressed $\gamma$-haemolysis (i.e. no haemolysis). Similar observations were made for Lactobacillus spp. isolated from dairy products [18], fermented olives [30] and 


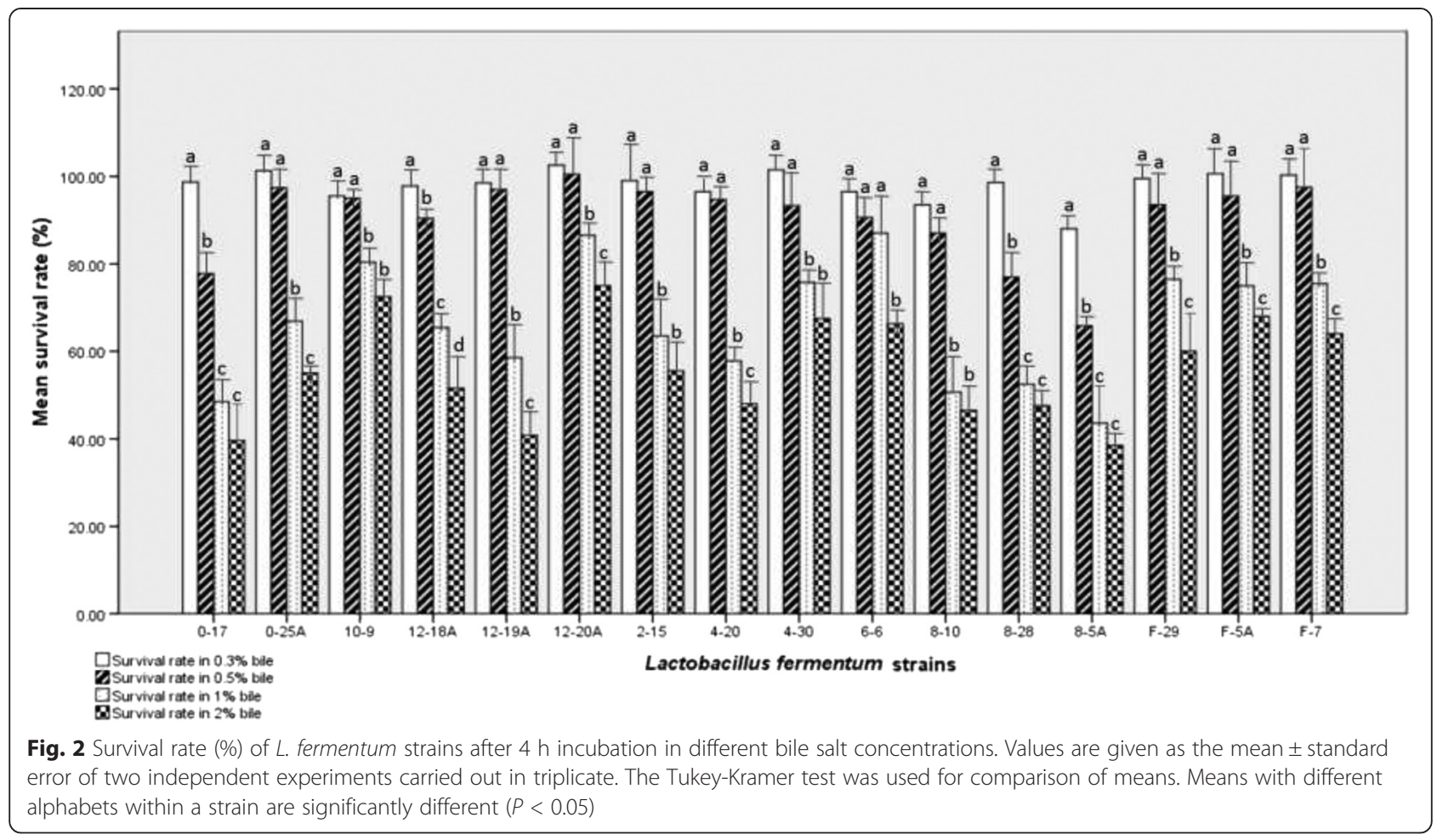

Table 3 Antagonistic activity of 16 L. fermentum strains against selected pathogens

\begin{tabular}{lll}
\hline Bacteria strain & ${ }^{a}$ Antagonistic activity & \\
\cline { 2 - 3 } & L. monocytogenes & Sta. aureus \\
& NCTC 10527 & ATCC 1448 \\
\hline L. fermentum 6-6 & - & - \\
L. fermentum f-7 & - & - \\
L. fermentum 10-9 & ++ & ++ \\
L. fermentum f-29 & - & - \\
L. fermentum 12-18A & - & - \\
L. fermentum 12-19A & - & - \\
L. fermentum 12-20A & - & - \\
L. fermentum 4-20 & + & ++ \\
L. fermentum 2-15 & - & - \\
L. fermentum 0-17 & ++ & ++ \\
L. fermentum 8-10 & - & - \\
L. fermentum 0-25A & - & - \\
L. fermentum f-5A & - & - \\
L. fermentum 8-5A & - & - \\
L. fermentum 8-28 & - & ++ \\
L. fermentum 4-30 & + & - \\
\hline antenic & + & -
\end{tabular}

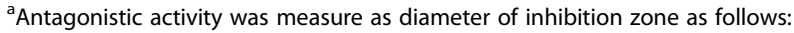
$(-)=<1 \mathrm{~mm},(+)=1-2 \mathrm{~mm},(++)=3-4 \mathrm{~mm},(+++)=>4 \mathrm{~mm}$. No antagonistic activity was observed towards others strains E. coli 0157882364 and S. enteritidis ATCC 13076 different African fermented food products [54]. The general absence of haemolysis or poor haemolytic activities expressed by lactic acid bacteria is indicative of their safety applications in food. In vitro assessment of haemolytic activity on blood agar is one of the safety requirements often used to assess potential probiotic strains [55]. On blood agar plates, microbial strains with $\beta$-haemolytic activity produce exotoxins which causes the lysis of blood cells, resulting in clearing of the zones around bacteria colonies.

\section{Antibiotic resistance}

Minimum inhibitory concentration (MIC) of 9 antibiotics determined for $16 \mathrm{~L}$. fermentum strains is shown in Table 4. Strains were considered resistant when they showed MIC values higher than the MIC breakpoints established by the European Food Safety Authority [56]. The majority of L. fermentum $(n=10)$ revealed low MICs for all tested antibiotics and are considered as non-resistant according to the EFSA breakpoint [56]. However, 6 strains showed resistance towards the protein synthesis inhibitor antibiotics streptomycin, kanamycin and gentamicin, mostly at low levels (MICs one to two log cycles above the cut-off point). [57] and [54] similarly reported gentamicin resistance in $L$. fermentum strains from African fermented foods.

Safety concerns regarding the use of probiotics containing antibiotic resistant strains arise due to the possibility of transferring antibiotic resistant genes to intestinal pathogens [58]. However, according to previous studies [59-61] 
Table 4 Minimum inhibitory concentrations of 9 antibiotics for $16 \mathrm{~L}$. fermentum strains isolated from traditional millet fermentation

\begin{tabular}{|c|c|c|c|c|c|c|c|c|c|}
\hline \multirow[t]{2}{*}{ Bacteria strain } & \multicolumn{9}{|c|}{ a MIC $(\mu \mathrm{g} / \mathrm{ml})$} \\
\hline & A & $\mathrm{C}$ & $\mathrm{T}$ & $\mathrm{F}$ & $\mathrm{S}$ & K & G & $\mathrm{Q} / \mathrm{D}$ & $\mathrm{CL}$ \\
\hline L. fermentum 6-6 & $<1$ & 2 & 2 & $<1$ & 8 & 16 & 8 & $<1$ & $<1$ \\
\hline L. fermentum f-7 & 1 & 4 & 4 & $<1$ & 32 & 32 & 4 & $<1$ & $<1$ \\
\hline L. fermentum 10-9 & 1 & 4 & 2 & 1 & $128^{\mathrm{b}}$ & 32 & $64^{b}$ & 1 & $<1$ \\
\hline L. fermentum f-29 & 1 & 2 & 2 & $<1$ & 4 & $64^{b}$ & $32^{\mathrm{b}}$ & $<1$ & $<1$ \\
\hline L. fermentum 12-18A & 1 & 1 & 2 & $<1$ & 8 & 8 & 16 & $<1$ & 1 \\
\hline L. fermentum 12-19A & $<1$ & 2 & 2 & $<1$ & $128^{\mathrm{b}}$ & $128^{b}$ & $32^{b}$ & $<1$ & $<1$ \\
\hline L. fermentum 12-20A & $<1$ & 2 & 8 & $<1$ & 8 & 32 & 16 & $<1$ & 1 \\
\hline L. fermentum 4-20 & 1 & 2 & 2 & $<1$ & 8 & 16 & 16 & $<1$ & 1 \\
\hline L. fermentum 2-15 & 1 & 1 & 2 & $<1$ & 32 & 32 & 8 & $<1$ & $<1$ \\
\hline L. fermentum 0-17 & 1 & 1 & 4 & $<1$ & 16 & $128^{b}$ & 16 & $<1$ & $<1$ \\
\hline L. fermentum 8-10 & 1 & 1 & 2 & 1 & $128^{\mathrm{b}}$ & $64^{\mathrm{b}}$ & $64^{b}$ & 2 & $<1$ \\
\hline L. fermentum 0-25A & 1 & $<1$ & 1 & 1 & 64 & 32 & 8 & $<1$ & $<1$ \\
\hline L. fermentum f-5A & 1 & $<1$ & 1 & $<1$ & 8 & 16 & 8 & $<1$ & $<1$ \\
\hline L. fermentum 8-5A & $<1$ & 2 & 4 & $<1$ & 8 & 16 & 16 & 1 & $<1$ \\
\hline L. fermentum 8-28 & 1 & 2 & 2 & $<1$ & $128^{\mathrm{b}}$ & $64^{b}$ & $32^{b}$ & 1 & $<1$ \\
\hline L. fermentum 4-30 & 1 & 1 & 2 & 1 & 64 & 8 & 16 & $<1$ & $<1$ \\
\hline
\end{tabular}

${ }^{\mathrm{a}} \mathrm{MIC}$ Minimum inhibitory concentration

${ }^{\mathrm{b}}$ Resistant according to the EFSA's breakpoints (EFSA, 2008)

$A$ ampicillin, $C$ chloramphenicol, $T$ tetracycline, $E$ erythromycin, $S$ streptomycin, $K$ kanamycin, $G$ gentamycin, $Q / D$ quinupristin/dalfopristin, $C L$ clindamycin

Table 5 Summary of the characteristics of $16 \mathrm{~L}$. fermentum strains with technological and probiotic potential according to in vitro tests

\begin{tabular}{|c|c|c|c|c|c|c|c|c|}
\hline \multirow{2}{*}{ Bacteria strain } & \multicolumn{3}{|c|}{ Technological properties } & \multicolumn{5}{|c|}{ Probiotic properties } \\
\hline & ${ }^{\mathrm{a}} \mathrm{RA}$ & ${ }^{\mathrm{b}}$ EPs & ${ }^{c} \mathrm{AA}$ & ${ }^{\mathrm{d}} \mathrm{AR}(\mathrm{SR} \%)$ & ${ }^{\mathrm{e}} \mathrm{RBS}(\mathrm{SR} \%)$ & ${ }^{9} \mathrm{BSHA}$ & ${ }^{\mathrm{i}} \mathrm{HA}$ & ${ }^{j} \mathrm{RAB}$ \\
\hline L. fermentum 6-6 & $\mathrm{F}$ & $\mathrm{H}$ & - & 83.0 & 96.5 & 0 & Y & - \\
\hline L. fermentum f-7 & $\mathrm{F}$ & $\mathrm{H}$ & - & 88.4 & 100.3 & 0 & $\gamma$ & - \\
\hline L. fermentum 10-9 & $\mathrm{F}$ & $\mathrm{H}$ & + & 86.8 & 95.5 & 1 & Y & $S, G$ \\
\hline L. fermentum f-29 & $\mathrm{F}$ & $\mathrm{H}$ & - & 88.2 & 99.5 & 1 & Y & $K, G$ \\
\hline L. fermentum 12-18A & $\mathrm{F}$ & $\mathrm{H}$ & - & 90.8 & 97.8 & 1 & $a$ & - \\
\hline L. fermentum 12-19A & $\mathrm{F}$ & $\mathrm{H}$ & - & 85.3 & 98.5 & 0 & Y & $\mathrm{S}, \mathrm{K}, \mathrm{G}$ \\
\hline L. fermentum 12-20A & $\mathrm{F}$ & $\mathrm{H}$ & + & 92.3 & 102.6 & 0 & Y & - \\
\hline L. fermentum 4-20 & $\mathrm{F}$ & $\mathrm{H}$ & + & 87.5 & 96.5 & 0 & $\gamma$ & - \\
\hline L. fermentum 2-15 & $\mathrm{F}$ & $\mathrm{H}$ & - & 90.3 & 99.0 & 0 & Y & - \\
\hline L. fermentum 0-17 & $\mathrm{F}$ & $\mathrm{H}$ & - & 85.6 & 98.7 & 1 & Y & K \\
\hline L. fermentum 8-10 & $\mathrm{F}$ & $\mathrm{H}$ & + & 82.5 & 93.5 & 0 & Y & $S, K, G$ \\
\hline L. fermentum 0-25A & $\mathrm{F}$ & $\mathrm{H}$ & - & 84.8 & 101.3 & 0 & $a$ & - \\
\hline L. fermentum f-5A & $\mathrm{F}$ & $\mathrm{H}$ & - & 91.6 & 100.6 & 0 & Y & - \\
\hline L. fermentum 8-5A & $\mathrm{F}$ & H & - & 80.6 & 88.0 & 0 & Y & - \\
\hline L. fermentum 8-28 & $\mathrm{F}$ & $\mathrm{H}$ & - & 91.1 & 98.6 & 0 & Y & $S, K, G$ \\
\hline L. fermentum 4-30 & $\mathrm{F}$ & $\mathrm{H}$ & - & 85.5 & 101.5 & 0 & $\gamma$ & - \\
\hline
\end{tabular}

${ }^{a} R A$ rate of acidification, $F$ fast acidifier

${ }^{\mathrm{b}}$ EPs Exopolysaccharides production, $H$ high potential EPs producer

${ }^{\mathrm{C}} A A$ amylase activity, - no amylase activity, + weak amylase activity

${ }^{\mathrm{d}} A R$ acid resistance measured as mean survival rate (\%)

${ }^{\mathrm{e}} \mathrm{RBS}$ resistance to $0.3 \%$ bile measured as mean survival rate (\%)

${ }^{9} B S H A$ bile salt hydrolase activity, 0 no hydrolysis, 1 partial hydrolysis

'HA haemolytic activity, $\mathrm{y}$-haemolysis, a-haemolysis

${ }^{\mathrm{j}} R A B$ resistance to antibiotics, $S$ streptomycin, $K$ kanamycin, $G$ gentamycin 
the antibiotic resistance observed for Lactobacillus strains are considered to be intrinsic or natural resistance because it is chromosomally encoded and, therefore, non-transmissible. Resistance to aminoglycoside antibiotics, such as gentamicin, streptomycin, kanamycin, is considered to be intrinsic in the Lactobacillus genus and is attributed to the absence of cytochromemediated electron transport, which mediates drug uptake $[60,62]$.

\section{Conclusion}

In conclusion, in vitro determination of technological and probiotic properties have shown strain specific difference among $L$. fermentum strains isolated from fermented millet dough. Sixteen (16) L. fermentum strains have been shown to possess desirable technological and probiotic characteristics in vitro as summarised in Table 5. These strains are therefore good candidates for further studies to elucidate their full potential and possible application as novel probiotic starter cultures.

\section{Abbreviations}

ATCC: American type culture collection; BHI: brain-heart infusion; BSH: bile salt hydrolysis; CFCS: cell-free culture supernatants; DNA: de-oxyribonucleic acid; EFSA: European food safety authority; EPS: exopolysaccharides; GIT: gastrointestinal tract; LAB: lactic acid bacteria; LB: Luria-Bertani; MIC: minimum inhibitory concentration; MRS: de Man, Rogosa and Sharpe; NB: nutrient broth; NCTC: National collection of type cultures; PBS: phosphatebuffered saline; PCR: polymerase chain reaction; PFGE: pulsed field gel electrophoresis; RAPD-DNA: randomly amplified polymorphic- de-oxyribonucleic acid; rRNA: ribosomal ribonucleic acid; TDCA: taurodeoxycholic acid; TS: tryptic soy.

\section{Competing interests}

The authors declare that they have no competing interests.

\section{Authors' contributions}

JOK participated in the project conception, carried out most of the experiment, analyzed and interpreted the data and wrote the manuscript. FA was the corresponding author, she carried out part of the laboratory analysis, and results interpretation, and reviewed the manuscript. KTD and LJ designed and supervised the entire project, participated in analysis and interpretation of results and corrected the manuscript. All authors read and approved the final manuscript.

\section{Acknowledgements}

This work was financed by the Danida (Danish International Development Agency, Ministry of Foreign Affairs) funded project: "Preserving African Food Microorganisms for Green Growth" DFC No. 13-04KU.

\section{Author details \\ 'Department of Applied Biology, Faculty of Applied Sciences, University for Development Studies, P. O. Box 24, Navrongo Campus, Navrongo, Ghana. ${ }^{2}$ Department of Nutrition and Food Science, University of Ghana, P. O. Box 134, Legon-Accra, Ghana. ${ }^{3}$ Department of Food Science, University of Copenhagen, Rolighedsvej 26, DK 1958 Frederiksberg C, Denmark.}

Received: 15 July 2015 Accepted: 6 November 2015 Published online: 11 November 2015

\section{References}

1. Owusu-Kwarteng J, Akabanda F, Nielsen DS, Tano-Debrah K, Glover RL, Jespersen L. Identification of lactic acid bacteria isolated during traditional fura processing in Ghana. Food Microbiol. 2012;32(1):72-8.
2. Pedersen LL, Owusu-Kwarteng J, Thorsen L, Jespersen L. Biodiversity and probiotic potential of yeasts isolated from Fura, a West African spontaneously fermented cereal. Int J Food Microbiol. 2012;159(2):144-51.

3. Vieira-Dalodé G, Jespersen L, Hounhouigan J, Moller P, Nago C, Jakobsen M. Lactic acid bacteria and yeasts associated with gowé production from sorghum in Bénin. J Appl Microbiol. 2007;103(2):342-9.

4. Nout MR. Rich nutrition from the poorest-Cereal fermentations in Africa and Asia. Food Microbiol. 2009;26(7):685-92.

5. Sieuwerts S, De Bok FA, Hugenholtz J, van Hylckama Vlieg JE. Unraveling microbial interactions in food fermentations: from classical to genomics approaches. Appl Environ Microbiol. 2008;74(16):4997-5007.

6. De Vuyst L, Schrijvers V, Paramithiotis S, Hoste B, Vancanneyt M, Swings J, et al. The biodiversity of lactic acid bacteria in Greek traditional wheat sourdoughs is reflected in both composition and metabolite formation. Appl Environ Microbiol. 2002;68(12):6059-69.

7. Okorie CP, Olasupo NA. Controlled fermentation and preservation of UGBAan indigenous Nigerian fermented food. Springer Plus. 2013;2(1):470.

8. Leroy F, De Vuyst L. Lactic acid bacteria as functional starter cultures for the food fermentation industry. Trends Food Sci Technol. 2004;15(2):67-78.

9. Hayford AE, Petersen A, Vogensen FK, Jakobsen M. Use of conserved randomly amplified polymorphic DNA (RAPD) fragments and RAPD pattern for characterization of Lactobacillus fermentum in Ghanaian fermented maize dough. Appl Environ Microbiol. 1999;65(7):3213-21.

10. Hounhouigan D, Nout M, Nago C, Houben J, Rombouts F. Characterization and frequency distribution of species of lactic acid bacteria involved in the processing of mawe, a fermented maize dough from Benin. Int J Food Microbiol. 1993; 18(4):279-87.

11. Lei V, Jakobsen M. Microbiological characterization and probiotic potential of koko and koko sour water, African spontaneously fermented millet porridge and drink. J Appl Microbiol. 2004;96(2):384-97.

12. Sawadogo-Lingani H, Lei V, Diawara B, Nielsen DS, Møller PL, Traore A, et al. The biodiversity of predominant lactic acid bacteria in dolo and pito wort for the production of sorghum beer. J Appl Microbiol. 2007;103(4):765-77.

13. Annan NT, Poll L, Sefa-Dedeh S, Plahar WA, Jakobsen M. Influence of starter culture combinations of Lactobacillus fermentum, Saccharomyces cerevisiae and Candida krusei on aroma in Ghanaian maize dough fermentation. Eur Food Res Technol. 2003;216(5):377-84.

14. Halm M, Lillie A, Sørensen A, Jakobsen M. Microbiological and aromatic characteristics of fermented maize doughs for kenkey production in Ghana. Int J Food Microbiol. 1993;19(2):135-43.

15. Guiraud J-P. Microbiologie alimentaire: dunod. 1998.

16. Knoshaug E, Ahlgren J, Trempy J. Growth associated exopolysaccharide expression in Lactococcus lactis subspecies cremoris Ropy352. J Dairy Sci. 2000;83(4):633-40.

17. Sanni A, Morlon-Guyot J, Guyot J. New efficient amylase-producing strains of Lactobacillus plantarum and L. fermentum isolated from different Nigerian traditional fermented foods. Int J Food Microbiol. 2002;72(1):53-62.

18. Maragkoudakis PA, Zoumpopoulou G, Miaris C, Kalantzopoulos G, Pot B, Tsakalidou E. Probiotic potential of Lactobacillus strains isolated from dairy products. Int Dairy J. 2006;16(3):189-99.

19. Zoumpopoulou G, Foligne B, Christodoulou K, Grangette C, Pot B, Tsakalidou E. Lactobacillus fermentum ACA-DC 179 displays probiotic potential in vitro and protects against trinitrobenzene sulfonic acid (TNBS)-induced colitis and Salmonella infection in murine models. Int J Food Microbiol. 2008;121(1):18-26.

20. Agati V, Guyot J-P, Morlon-Guyot J, Talamond P, Hounhouigan D. Isolation and characterization of new amylolytic strains of Lactobacillus fermentum from fermented maize doughs (mawe and ogi) from Benin. J Appl Microbiol. 1998;85(3):512-20.

21. Xiaodong W, Xuan G, Rakshit S. Direct fermentative production of lactic acid on cassava and other starch substrates. Biotechnol Lett. 1997;19(9):841-3.

22. Yumoto I, Ikeda K. Direct fermentation of starch to L-(+)-lactic acid using Lactobacillus amylophilus. Biotechnol Lett. 1995;17(5):543-6.

23. Joint F, Organization WH. Application of risk analysis to food standards issues: report of the Joint FA. 1995.

24. De Vuyst $\mathrm{L}$, Degeest B. Heteropolysaccharides from lactic acid bacteria. FEMS Microbiol Rev. 1999;23(2):153-77.

25. Patel S, Majumder A, Goyal A. Potentials of exopolysaccharides from lactic acid bacteria. Indian J Microbiol. 2012;52(1):3-12.

26. Fanning S, Hall $\sqcup$, Cronin M, Zomer A, MacSharry J, Goulding D, et al. Bifidobacterial surface-exopolysaccharide facilitates commensal-host 
interaction through immune modulation and pathogen protection. Proc Natl Acad Sci. 2012;109(6):2108-13.

27. Weiner R, Langille S, Quintero E. Structure, function and immunochemistry of bacterial exopolysaccharides. J Ind Microbiol. 1995;15(4):339-46.

28. Kojic M, Jovcic B, Strahinic I, Begovic J, Lozo J, Veljovic K, et al. Cloning and expression of a novel lactococcal aggregation factor from Lactococcus lactis subsp. lactis BGKP1. BMC Microbiol. 2011;11(1):265.

29. Walter J, Schwab C, Loach DM, Gänzle MG, Tannock GW. Glucosyltransferase A (GtfA) and inulosucrase (Inu) of Lactobacillus reuteri TMW1. 106 contribute to cell aggregation, in vitro biofilm formation, and colonization of the mouse gastrointestinal tract. Microbiology. 2008;154(1):72-80.

30. Argyri AA, Zoumpopoulou G, Karatzas K-AG, Tsakalidou E, Nychas G-JE, Panagou EZ, et al. Selection of potential probiotic lactic acid bacteria from fermented olives by in vitro tests. Food Microbiol. 2013;33(2):282-91.

31. Bao Y, Zhang Y, Zhang Y, Liu Y, Wang S, Dong X, et al. Screening of potential probiotic properties of Lactobacillus fermentum isolated from traditional dairy products. Food Control. 2010;21(5):695-701.

32. Du Toit M, Franz C, Dicks L, Schillinger U, Haberer P, Warlies B, et al. Characterisation and selection of probiotic lactobacilli for a preliminary minipig feeding trial and their effect on serum cholesterol levels, faeces $\mathrm{pH}$ and faeces moisture content. Int J Food Microbiol. 1998;40(1):93-104.

33. Dunne C, O'Mahony L, Murphy L, Thornton G, Morrissey D, O'Halloran S, et al. In vitro selection criteria for probiotic bacteria of human origin: correlation with in vivo findings. Am J Clin Nutr. 2001;73(2):386s-92.

34. Ramos C, Thorsen L, Schwan R, Jespersen L. Strain-specific probiotics properties of Lactobacillus fermentum, L. plantarum and L. brevis isolates from Brazilian food products. Food Microbiol. 2013;36:22-9.

35. Jacobsen CN, Nielsen VR, Hayford A, Møller P, Michaelsen K, Paerregaard A, et al. Screening of probiotic activities of forty-seven strains of Lactobacillus spp. by in vitro techniques and evaluation of the colonization ability of five selected strains in humans. Appl Environ Microbiol. 1999;65(11):4949-56.

36. Pennacchia C, Ercolini D, Blaiotta G, Pepe O, Mauriello G, Villani F. Selection of Lactobacillus strains from fermented sausages for their potential use as probiotics. Meat Sci. 2004;67(2):309-17.

37. Nagpal R, Kumar A, Kumar M, Behare PV, Jain S, Yadav H. Probiotics, their health benefits and applications for developing healthier foods: a review. FEMS Microbiol Lett. 2012;334(1):1-15

38. Lee Y-K, Salminen S. The coming of age of probiotics. Trends Food Sci Technol. 1995;6(7):241-5.

39. Bove P, Gallone A, Russo P, Capozzi V, Albenzio M, Spano G, et al. Probiotic features of Lactobacillus plantarum mutant strains. Appl Microbiol Biotechnol. 2012;96(2):431-41.

40. Corcoran B, Stanton C, Fitzgerald G, Ross R. Life under stress: the probiotic stress response and how it may be manipulated. Curr Pharm Des. 2008;14(14):1382-99.

41. Begley M, Gahan CG, Hill C. The interaction between bacteria and bile. FEMS Microbiol Rev. 2005;29(4):625-51.

42. Tuomola E, Crittenden R, Playne M, Isolauri E, Salminen S. Quality assurance criteria for probiotic bacteria. Am J Clin Nutr. 2001;73:393s-8.

43. Solieri L, Bianchi A, Mottolese G, Lemmetti F, Giudici P. Tailoring the probiotic potential of non-starter Lactobacillus strains from ripened Parmigiano Reggiano cheese by in vitro screening and principal component analysis. Food Microbiol. 2014;38:240-9.

44. Zago M, Fornasari ME, Carminati D, Burns $P$, Suàrez V, Vinderola $G$, et al. Characterization and probiotic potential of Lactobacillus plantarum strains isolated from cheeses. Food Microbiol. 2011;28(5):1033-40.

45. Begley M, Hill C, Gahan CG. Bile salt hydrolase activity in probiotics. Appl Environ Microbiol. 2006;72(3):1729-38.

46. Liong M, Shah N. Acid and bile tolerance and cholesterol removal ability of lactobacilli strains. J Dairy Sci. 2005;88(1):55-66

47. Smet ID, Hoorde LV, Saeyer ND, Woestyne MV, Verstraete W. In vitro study of bile salt hydrolase (BSH) activity of BSH isogenic Lactobacillus plantarum 80 strains and estimation of cholesterol lowering through enhanced BSH activity. Microb Ecol Health Dis. 1994;7(6):315-29.

48. Lin WH, Yu B, Lin CK, Hwang WZ, Tsen HY. Immune effect of heat-killed multistrain of Lactobacillus acidophilus against Salmonella typhimurium invasion to mice. J Appl Microbiol. 2007;102(1):22-31.

49. Millette $M$, Luquet F, Lacroix M. In vitro growth control of selected pathogens by Lactobacillus acidophilus-and Lactobacillus casei-fermented milk. Lett Appl Microbiol. 2007;44(3):314-9.

50. Lu L, Walker WA. Pathologic and physiologic interactions of bacteria with the gastrointestinal epithelium. Am J Clin Nutr. 2001;73(6):1124S-30.
51. Reid G, Kim SO, Köhler GA. Selecting, testing and understanding probiotic microorganisms. FEMS Immunol Med Microbiol. 2006;46(2):149-57.

52. Ouwehand AC, Salminen SJ. The health effects of cultured milk products with viable and non-viable bacteria. Int Dairy J. 1998;8(9):749-58.

53. Gänzle MG, Hertel C, van der Vossen JM, Hammes WP. Effect of bacteriocin-producing lactobacilli on the survival of Escherichia coli and Listeria in a dynamic model of the stomach and the small intestine. Int J Food Microbiol. 1999;48(1):21-35.

54. Adimpong DB, Nielsen DS, Sørensen Kl, Derkx PM, Jespersen L. Genotypic characterization and safety assessment of lactic acid bacteria from indigenous African fermented food products. BMC Microbiol. 2012;12(1):75

55. Joint F. WHO Working Group on Drafting Guidelines for the Evaluation of Probiotics in Food. Guidelines for the evaluation of probiotics in food: report of a Joint FAO/WHO Working Group on Drafting Guidelines for the Evaluation of Probiotics in Food, London, Ontario, Canada, April 30 and May 1, 2002. ftp fao org/es/esn/food/wgreport2 pdf Accessed 2007, 16.

56. EFSA. Technical guidance prepared by the Panel on Additives and Products or Substances used in Animal Feed (FEEDAP) on the update of the criteria used in the assessment of bacterial resistance to antibiotics of human or veterinary importance. EFSA J. 2008;732:1-15.

57. Ouoba LII, Lei $V$, Jensen LB. Resistance of potential probiotic lactic acid bacteria and bifidobacteria of African and European origin to antimicrobials: determination and transferability of the resistance genes to other bacteria. Int J Food Microbiol. 2008;121(2):217-24.

58. Curragh HJ, Collins M. High levels of spontaneous drug resistance in Lactobacillus. J Appl Bacteriol. 1992;73(1):31-6.

59. Charteris WP, Kelly PM, Morelli L, Collins JK. Gradient diffusion antibiotic susceptibility testing of potentially probiotic lactobacilli. J Food Prot. 2001;64(12):2007-14.

60. Danielsen M, Wind A. Susceptibility of Lactobacillus spp. to antimicrobial agents. Int J Food Microbiol. 2003;82(1):1-11.

61. Katla A-K, Kruse H, Johnsen G, Herikstad H. Antimicrobial susceptibility of starter culture bacteria used in Norwegian dairy products. Int J Food Microbiol. 2001;67(1):147-52.

62. Monteagudo-Mera A, Rodríguez-Aparicio L, Rúa J, Martínez-Blanco H, Navasa N, García-Armesto MR, et al. In vitro evaluation of physiological probiotic properties of different lactic acid bacteria strains of dairy and human origin. J Funct Foods. 2012;4(2):531-41.

\section{Submit your next manuscript to BioMed Central and take full advantage of:}

- Convenient online submission

- Thorough peer review

- No space constraints or color figure charges

- Immediate publication on acceptance

- Inclusion in PubMed, CAS, Scopus and Google Scholar

- Research which is freely available for redistribution 